\title{
KINERJA KEUANGAN LAYANAN KESEHATAN SEBELUM DAN SESUDAH PENERAPAN PPK BLU
}

\author{
Ratna Suryaningsih \\ RSUP Dr. Soeradji Tirtonegoro
}

\begin{abstract}
This study aimed to analyze the differences in performance of financial ratios Dr. Soeradji Tirtonegoro hospital before and after application of "Pola Pengelolaan Keuangan Badan Layanan Umum" / PPK BLU. The ratio is based on conscientious Director General of Treasury Regulation No. Per-36/PB/2012.

The data used in this study were obtained from financial ratios of $\mathrm{Dr}$. Soeradji Tirtonegoro hospital during the period 2002-2012. This study examines the financial performance consisted of Cash Ratio, Current Ratio, Collection Period, Fixed asset turnover, Return on assets and Return on equity. While the performance of services in representing the growth of competitiveness in proksikan by Sales Growth (SALG) and Activity Growth. Processing of the data in this study performed using a statistical technique Uji Beda T-test dengan Related Samples or paired samples often diistilakan with t-test.

The findings of this study indicate that the Cash Ratio Dr. Soeradji Tirtonegoro hospital after applying the PPK-BLU better than before KDP - BLU. For another study that ratio, Current ratio, Collection Period ,Ffixed asset turnover, Return on assets, Return on equity, Sales Growth ( SALG ) and Growth Activity Dr. Soeradji Tirtonegoro hospital not have a significant difference after applying the PPK-BLU with before PPKBLU.
\end{abstract}

Keywords : PPK - BLU, financial ratio performance, Paired Sample t- Test

\begin{abstract}
ABSTRAK
Penelitian ini bertujuan untuk menganalisis perbedaan kinerja rasio keuangan RSUP $\mathrm{dr}$. Soeradji Tirtonegoro sebelum dan sesudah penerapan PolaPengelolaan Keuangan Badan Layanan Umum (PPK BLU). Adapun rasio yang teliti berdasarkan dari Peraturan Direktur Jenderal Perbendaharaan Nomor Per36/PB/2012.

Data yang dipergunakan dalam penelitian ini diperoleh dari rasio keuangan RSUP Dr. Soeradji Tirtonegoro selama periode, 2002-2012. Penelitian ini menguji kinerja keuangan terdiri dari Cash Ratio, Current Ratio, Collection Period, fixed asset turnover, return on asset dan return on equity. Sedangkan kinerja pelayanan di wakili pertumbuhan daya saing di proksikan oleh Sales Growth (SALG)dan Activity Growth.Pengolahan data dalam penelitian ini dilakukan dengan menggunakan teknik statistik yang berupa Uji Beda T-test dengan Related Samples atau sering diistilakan dengan Paired Sampel t-Test.
\end{abstract}


Temuan penelitian ini menunjukkan bahwa Cash RatioRSUP dr. Soeradji Tirtonegoro sesudah menerapkan PPK-BLU lebih baik dibandingkan dengan sebelum PPK-BLU.Untuk rasio penelitian yang lain yakni, Current Ratio, Collection Period, fixed asset turnover, return on asset, return on equity, Sales Growth (SALG) dan Activity GrowthRSUP dr. Soeradji Tirtonegoro tidak memiliki perbedaan yang signifikan sesudah menerapkan PPK-BLU dengan sebelum PPK-BLU.

Kata kunci: PPK-BLU, Kinerja rasio keuangan, Paired Sampel t-Test

Problem umum yang krusial di Indonesia sekarang adalah adanya berbagai fenomena diantaranya adalah peristiwa korupsi, kolusi dan nepotisme.Praktek KKN ini terjadi begitu massif disemua jajaran baik eksekutif maupun pihak-pihak lainnya. Problem berikutnya adalah bangsa kita Indonesia masih memiliki peringkat Human Development

Indicator (http://hdr.undp.org/en) jajaran terendah, urutan ke 121 negara-negara di dunia di tahun 2012. Problem Ketiga, bahwa mahalnya biaya hidup yang dirasakan masyarakat, terutama oleh sebagian besar penduduk dari pedesaan dan masyarakat miskin di perkotaan. Dari ketiga hal ini dapat dijadikan cerminan atas hubungan pelaksanaan pelayanan publik di suatu negara.Sehingga tidak aneh jika terdengar di suatu media tentang adanya berbagai kasus mulai dari sulitnya warga negara memperoleh akses pelayanan maupun buruknya kualitas pelayanan oleh aparatur/instansi dibanyak sektor.Pelayanan publik yang sudah dilaksanakan masih belum terdapat standar pelayanan minimal dan belum terintegrasi baik guna mewujudkan pelayanan yang cepat, tepat, murah, dan memuaskan.Tuntutan penyelenggaraan pelayanan umum yang transparan, akuntabel, efektif dan efisien menjadi tantangan bagi penyelenggaraan pemerintahan dalam melayani masyarakat.

Dalam usaha memperbaiki pandangan dan penilaian masyarakat mengenai pelayanan publik di Indonesia selama dua dekade terakhir, pemerintah telah melaksanakan reformasi administrasi publik. Reformasi administrasi publik atau Dotrin New Public Management(NPM)/Reinventing Government yang telah sukses dilakukan negara-negara Eropa, Amerika Serikat, Australia, dan Selandia Baru secara berangsur-angsur diadopsi ke dalam manajemen pemerintahan di berbagai negara, termasuk Indonesia. Transformasi manajemen pemerintahan dalam New Public Management mulai dari penataan kelembagaan (Institutional Arrangement), reformasi kepegawaian (Civil Servant Reform), dan reformasi pengelolaan keuangan Negara (New Management Reform) (Mahmudi, 2005).

Dalam upaya meningkatkan layanan kepada publik, maka diperlukan pengaturan yang spesifik mengenai satuan kerja pemerintahan yang melakukan pelayanan kepada masyarakat yang saat ini bentuknya beraneka macam.Usaha pemerintah memperbaiki layanan kepada publik dengan mengeluarkan Undang-Undang Nomor 23 Tahun 2005 tentang Pengelolaan Keuangan Badan Layanan Umum. Dalam peraturan Menteri Keuangan Nomor 119/pmk.05/2007 dibunyikan bahwa Pengelolaan Keuangan Badan Layanan Umum yang selanjutnya disingkat PK BLU adalah pengelolaan keuangan yang memberikan fleksibilitas berupa keleluasaan untuk menerapkan praktekpraktek bisnis yang sehat untuk meningkatkan pelayanan kepada 
masyarakat dalam rangka memajukan kesejahteraan dan mencerdaskan kehidupan bangsa, sebagai pengecualian dari ketentuan pengelolaan keuangan negara pada umumnya. Tujuan dibentuknya organisasi penyelenggara pelayanan publik menjadi Badan Layanan Umum (BLU) adalah peningkatan kinerja pelayanan publik menjadi lebih baik.Perubahan status menjadi BLU diharapkan dapat memperbaiki kinerja penyelenggara pelayanan publik, khususnya dalam hal pengelolaan keuangan.BLU pada dasarnya adalah alat untuk meningkatkan kinerja pelayanan publik melalui penerapan manajemen keuangan yang berbasis pada hasil, profesionalitas, akuntabilitas dan transparansi.

RSUP dr. Soeradji Tirtonegoro Klaten sebagai salah satu sub system penyelenggaraan peningkatan kesehatan memiliki peran dalam penyelenggaraan pelayanan kesehatan melalui tenaga dokter yang profesional, peralatan medis, pelayanan laboratorium, farmasi, pelayanan perawatan, penelitian dan pendidikan tenaga dokter dan paramedis. Biaya kesehatan cenderung terus meningkat,dan rumah sakit dituntut untuk secara mandiri mengatasi masalah tersebut. Peningkatan biaya kesehatan ini menyebabkan fenomena tersendiri bagi rumah sakit pemerintahan karena rumah sakit pemerintah memiliki segmen layanan kesehatan sebagian besar untuk kalangan menengah ke bawah.Akibatnya rumah sakit pemerintah diharapkan menjadi rumah sakit yang murah dan bermutu.

Untuk menjawab tuntutan dan permasalahan tersebut pada tahun 2007 berdasar Keputusan Menteri Keuangan Nomor 273/KMK 05/2007 tanggal 21 Juni 2007 dan keputusan Menteri Kesehatan RI Nomor 756/Menkes/SK/VI/2007 tanggal 26 Juni 2007 RSUP dr. Soeradji Tirtonegoro ditetapkan sebagai Rumah Sakit Pola Pengelolaan Keuangan Badan Layanan Umum (RSPPK BLU). Dengan ditetapkannya
RSUP dr. Soeradji Tirtonegoro sebagai RSPPK BLU memungkinkan RSUP dr. Soeradji Tirtonegoro dapat mengelola secara langsung pendapatan yang diperoleh serta merencanakan, mengelola, dan mengendalikan semua urusan internal rumah sakit secara lebih fleksibel. Semua itu demi meningkatkan kualitas pelayanan terhadap masyarakat.

Penelitian yang dilakukan Meidyawati (2012) dengan judul Implementasi Pola Pengelolaan Keuangan Badan Layanan Umum (PPK-BLU) pada Rumah Sakit Stroke Nasional Bukittinggi meneliti tentang implementasi Pola Pengelolaan Keuangan Badan Layanan Umum (PPKBLU) pada Rumah Sakit Stroke Nasional Bukittinggi telah berjalan sesuai dengan konsep dan aturan Pola Pengelolaan Keuangan Badan Layanan Umum (PPKBLU) atau tidak. Adapun analisa yang dipergunakan dalam penelitian tersebut adalah SWOT.Trianasari dan Idrus (2012) pada penelitian dengan judul The Strategic Evaluation Of RSUD DR. Saiful Anwar (RSSA) Malang Before and After Being Badan Layanan Umum Daerah (BLUD) mencoba melakukan evaluasi strategi pada RSUD Dr. Saiful Anwar (RSSA) Malang sebelum dan sesudah Badan Layanan Umum Daerah (BLUD), yaitu dari tahun 2007 sampai dengan 2011. Metode pengolahan data menggunakan Balanced Scorecard dengan strategi pengumpulan data secara ganda (triangulasi).Maharani (2013), melakukan penelitian mengenai BLU.Tujuan dari penelitian ini adalah untuk mengetahui perbedaan kinerja keuangan sebelum dan sesudah diterapkannya Pola Pengelolaan Keuangan Badan Layanan Umum di Universitas Seb elas Maret Surakarta.

Perbedaan dengan penelitian Maharani (2013) adalah pada penelitian yang dilakukan peneliti, obyek penelitiannya di Rumah Sakit, khususnya RSUP Dr. Soeradji Tirtonegoro Klaten, sedangkan penelitian Maharani (2013) dilakukan di Universitas Sebelas Maret Surakarta. Perbedaan kedua terletak pada 
variable penelitian, yaitu pada penelitian Maharani (2013) hanya menggunakan rasio keuangan saja, sedang peneliti selain menggunakan rasio keuangan juga menggunakan rasio pelayanan. Perbedaan berikutnya adalah pada penelitian Maharani (2013), rasio keuangan yang dipakai adalah rasio keuangan untuk sektor publik, sedangkan rasio keuangan yang dipakai peneliti adalah rasio keuangan berdasarkan pada pedoman penilaian kinerja keuangan BLU sesuai peraturan Dirjen Perbendaharaan nomor 36/PER/2012 dan dengan menambahkan rasio pelayanan berdasar pada KEPMENKES NO. 209/MENKES/SK/I/2011

Dari uraian masalah yang telah dibahas sebelumnya, peneliti merasa perlu mengadakan suatu penelitian yang bertujuan untuk mengetahui perbedaan kinerja keuangan dan kinerja pelayanan RSUP $d r$. Soeradji Tirtonegoro sebelum ditetapkan sebagai Rumah Sakit Pola Pengelolaan Keuangan Badan Layanan Umum (PK BLU) dengan sesudah ditetapkan sebagai Rumah Sakit Pola Pengelolaan Keuangan Badan Layanan Umum (PK BLU). Adapun kinerja keuangan terdiri dari Cash Ratio, Current Ratio, Collection Period, fixed asset turnover,return on asset dan return on equity. Sedangkan kinerja pelayanan di wakili pertumbuhan daya saing di proksikan oleh Sales Growth (SALG)d an Activity Growth.

\section{TINJAUAN PUSTAKA}

\section{Teori Siklus Hidup (Life Cycle Theory)}

Teori siklus hidup produk (product life cycle) adalah salah satu teori penjelasan yang paling umum dalam literatur manajemen perubahan.Mowen (2006) menyatakan bahwa daur hidup produk secara sederhana adalah waktu keberadaan produk, dari pengkonsepan hingga tidak terpakai.Biaya daur hidup adalah semua biaya yang berhubungan dengan produk untuk keseluruhan daur hidupnya. Hal ini meliputi pengembangan (perencanaan, rancangan, dan pengujian), produksi, dan dukungan logistik (pengiklanan dan pendistribusian). Teori siklus hidup produk mempunyai anggapan bahwa setiap produk akan mengalami evolusi atau memiliki kehidupan, usia dan tahap-tahap yang berarti seperti kelahiran, pertumbuhan, kematangan, penurunan dan kematian. Di setiap tahap tersebut mempunyai ciri-ciri tertentu.Terdapat empat fase dalam evolusi siklus hidup suatu perusahaan, yaitu fase perkenalan (introduction/pioneering), pertumbuhan (growth/expansion), kematangan (mature/ harvest), dan penurunan (decline).

Uraian teori siklus hidup produk (product life cycle) diatas dapat dijadikan sebagai dasar teori dari penelitian dimana perubahan status unit kerja Instansi Pemerintah ke Pola Pengelolaan Keuangan Badan Layanan Umum (PPK-BLU) memberikan fleksibilitas pengelolaan keuangan kepada instansi pemerintah yang telah berstatus BLU untuk secara langsung dapat menggunakan penerimaannya bagi kegiatan operasional dan investasi tanpa harus disetor terlebih dahulu ke kas negara, demikian juga dengan surplus yang diperolehnya. Fleksibilitas pengelolaan keuangan BLU diberikan berdasarkan prinsip ekonomi, produktivitas dan penerapan praktek bisnis yang sehat.Konsep PPK-BLU adalah peningkatan profesionalisme, mendorong entrepreneurship, transparansi, dan akuntabilitas dalam rangka pelayanan publik.

\section{Kinerja Keuangan}

Pengertian kinerja menurut Bastian (2006) adalah gambaran pencapaian pelaksanaan / program / kebijaksanaan dalam mewujudkan sasaran, tujuan, misi dan visi suatu organisasi.Kinerja keuangan adalah untuk menilai kondisi keuangan dan prestasi perusahaan, analisis memerlukan beberapa tolak ukur yang digunakan yaitu 
ratio dan indeks, yang menghubungkan dua data keuangan antara satu dengan yang lain (Sawir, 2005). Kinerja keuangan yang dipergunakan dalam penelitian ini meliputi Cash Ratio, Current Ratio, Collection period, Fixed Asset Turnover, Return on AssetdanReturn on Equity.

1. Cash Ratio

Pengertian Cash Ratio menurut Munawir (2001)merupakanperbandingan antara kas dengan total hutang lancar, atau dapat juga dihitung dengan mengikutsertakan surat-surat berharga (Marketable Securities)."

2. Current Ratio

Menurut Munawir (2005) Rasio yang paling umum digunakan untuk menganalisis posisi modal kerja suatu perusahaan adalah current ratio yaitu perbandingan antara jumlah aktiva lancar dengan hutang lancar.

3. Collection Period

Periode Penagihan Piutang mengukur berapa lama penagihan piutang selama periode atau berapa kali dana yang ditanam dalam piutang berputar dalam suatu periode. Semakin kecil periode penagihan piutang semakin baik.

4. Fixed Asset Turnover

Menurut Beams ( 2004) perputaran aktiva tetap adalah "Posisi aktiva Tetap dan taksiran waktu perputaran aktiva tetap dapat dinilai dengan menghitung tingkat perputaran aktiva tetap yaitu, dengan membagi penjualan dengan total aktiva tetap bersih".Maka dapat disimpulkan bahwa perputaran aktiva tetap ditentukan oleh 2 faktor utama yaitu, penjualan dan total aktiva tetap bersih. Yang dimaksud total aktiva tetap bersih adalah total aktiva tetap setelah dikurangi penyusutan aktiva tetap.

5. Return on Asset

Menurut Henry Simamora (2006) mendefinisikan Return on Asset yaitu "Return on Asset (ROA) merupakan suatu ukuran keseluruhan profitabilitas perusahaan".Dari definisi-definisi di atas maka dapat ditarik kesimpulan bahwa Return on Asset merupakanrasio yang dipakai untuk mengevaluasi apakah manajemen telah mendapat imbalan yang memadai ( reasobable return ) dari asset yang dikuasainya.

6. Return on Equity

Definisi Return On Equity (ROE) menurut Sutrisno (2005) adalah kemampuan perusahaan dalam menghasilkan keuntungan modal sendiri yang dimiliki."Menurut Sawir (2003) Return On Equity (ROE) merupakan sebuah rasio yang sering dipergunakan oleh pemegang saham untuk menilai kinerja perusahaan yang bersangkutan.

\section{Kinerja Pelayanan}

Kinerja pelayanan adalah hasil kerja secara kualitas dan kuantitas yang dicapai oleh seorang pegawai dalam melaksanakan tugasnya dalam memenuhan kebutuhan orang lain secara langsung baik berbentuk pelayanan barang dan jasa.

Kinerja pelayanan rumah sakit dinilai berdasarkan beberapa indiklator.Adapun indikator yang dijadikan penilaian menurut KEPMENKES

NO.209/MENKES/SK/l/2011adalah

pertumbuhan produktivitas, efisiensi pelayanan, pertumbuhan daya saing, pengembangan SDM, penelitian dan pengembangan serta administrasi.Dalam penelitian ini kinerja pelayanan diproksikan pada pertumbuhan daya saing. Adapun rasio yang dipergunakan adalah Sales Growth (SALG) dan Activity G rowth.

1. Sales Growth (SALG)

Menurut NO.209/MENKES/SK/I/2011 yang dimaksud dengan Sales Growth adalah gambaran tingkat pelayanan yang dapat dilihat dari peningkatan pendapatan Rumah Sakit.

2. Activity Growth

Yang dimaksud dari Activity Growth adalah gambaran pertumbuhan tingkat pelayanan dari peningkatan volume 
Jurnal Bisnis \& M anajemen

Vol. 15, N 0. 1, $2015: 57$ - 80

kegiatan (KEPMENKES NO

209/MENKES/SK/I/2011).

\section{Badan Layanan Umum (BLU)}

1. Pengertian Badan Layanan Umum (BLU)

"Badan Layanan Umum / BLU adalah instansi di lingkungan Pemerintah yang dibentuk untuk memberikan pelayanan kepada masyarakat berupa penyediaan barang dan/atau jasa yang dijual tanpa mengutamakan mencari keuntungan dan dalam melakukan kegiatannya didasarkan pada prinsip efisiensi dan produktivitas". Pengertian Badan Layanan Umum (BLU) ini diatur dalam Pasal 1 angka 23 UU Nomor 1 Tahun 2004 tentang Perbendaharaan Negara, yang kemudian diadopsi kembali dalam peraturan pelaksanaannya yaitu dalam Pasal 1 angka 1 Peraturan Pemerintah Nomor 23 Tahun 2005 tentang Pengelolaan Keuangan Badan Layanan Umum.

2. Tujuan Dibentuknya Badan Layanan Umum (BLU)

Dalam PP No.23 tahun 2005 pasal 2 menyebutkan bahwa "BLU bertujuan untuk meningkatkan pelayanan kepada masyarakat dalam rangka memajukan kesejahteraanumum dan mencerdaskan kehidupan bangsa dengan memberikan fleksibilitas dalam pengelolaan keuangan berdasarkan prinsip ekonomi dan produktifitas dan penerapan praktek bisnis yang sehat.

3. Azas Badan Layanan Umum (BLU)

Azas Badan Layanan Umum (BLU) Menurut pasal 3 PP No.23 Tahun 2005, dapat disimpulkan yaitu :

a. Menyelenggarakan pelayanan umum yang pengelolaannya berdasarkan kewenangan yang di delegasikan, tidak terpisah secara hukum dari instansi induknya. b. Pejabat BLU bertanggung jawab atas pelaksanaan kegiatan layanan umum kepada pimpinan instansi induk.

c. BLU tidak mencari laba

d. Rencana kerja, anggaran dan laporan BLU dari instansi induk tidak terpisah

e. Pengelolaan sejalan dengan praktek bisnis yang sehat

4. Jenis Badan Layanan Umum (BLU)

Apabila dikelompokkan menurut jenisnya Badan Layanan Umum terbagi menjadi 3 kelompok, yaitu:

a. BLU yang kegiatannya menyediakan barang atau jasa meliputi rumah sakit, lembaga pendidikan, pelayanan lisensi, penyiaran, dan lain-lain;

b. BLU yang kegiatannya mengelola wilayah atau kawasan meliputi otorita pengembangan wilayah dan kawasan ekonomi terpadu (Kapet); dan

c. BLU yang kegiatannya mengelola dana khusus meliputi pengelola dana bergulir, dana UKM, penerusan pinjaman dan tabungan pegawai.

5. Peraturan Direktur Jenderal PerbendaharaanNomor PER-36/PB/2012

Peraturan Direktur Jenderal Perbendaharaan Nomor Per-36/PB/2012 merupakan peraturan pemerintah yang mengatur tentang pedoman penilaian kinerja keuangan Satuan Kerja Badan Layanan Umum. Peraturan Direktur Jenderal Perbendaharaan ini mengatur mengenai pedoman penilaian kinerja keuangan Satker BLU, yang meliputi Aspek Keuangan dan Aspek Kepatuhan Pengelolaan Keuangan BLU.Dalam penelitian ini yang akan diteliti merupakan Rasio Keuangan dari Aspek Keuangan Badan Layanan Umum yang telah ditentukan perhitungannya oleh peraturan ini. 
Sebelum Penerapan PPK BLU Sesudah Penerapan PPK BLU

\begin{tabular}{|c|}
\hline $\begin{array}{l}\quad \text { Rasio Keuangan : } \\
\text { - } \text { Cash Ratio } \\
\text { - } \text { Current Ratio } \\
\text { - } \text { Collection Period } \\
\text { - } \text { Fixed Asset Turnover } \\
\text { - } \text { Return on Asset(ROA) } \\
\text { - Return On Equity(ROE) } \\
\text { - Kinerja Pelayanan : } \\
\text { - } \text { Sales Growth (SALG) } \\
\text { Activity Growth }\end{array}$ \\
\hline
\end{tabular}

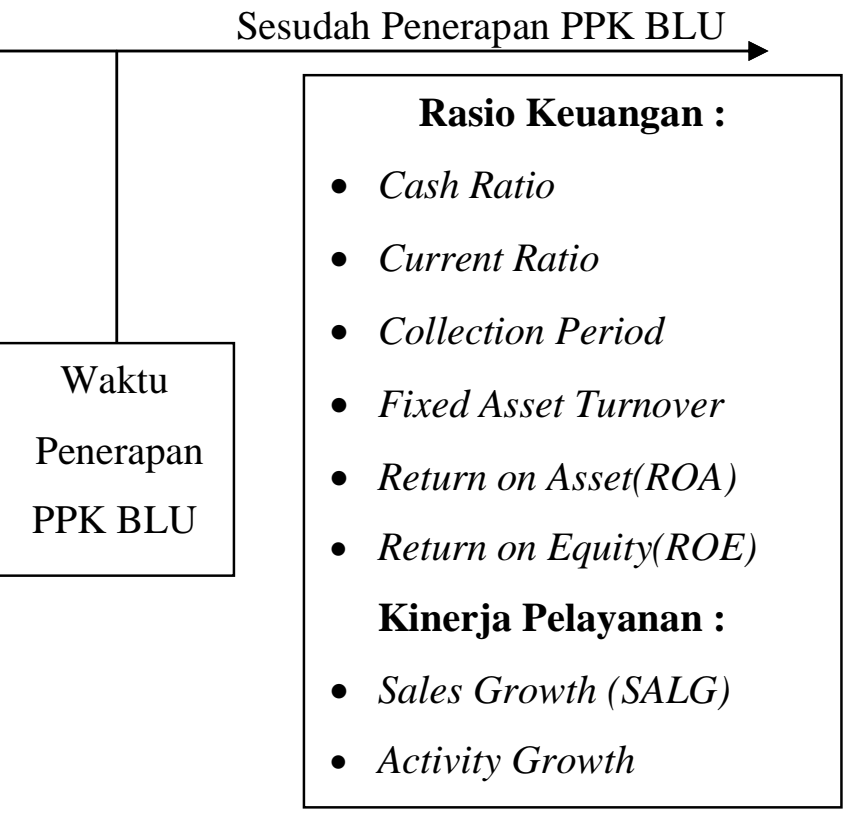

Gambar 1.Kerangka Pemikiran

Berdasarkan kerangka pemikiran teoritis terhadap rumusan masalah penelitian ini dan Peraturan Pemerintah Nomor 23 Tahun 2005 tentang Pengelolaan Keuangan Badan Layanan Umum menyatakan penerapan PPKBLUdianggap berhasil jika nilai kinerja keuangan maupun pelayanan lebih baik di bandingkan sebelum penerapan PPK-BLU, maka hipotesis yang diajukan adalah sebagai berikut:

1. Cash Ratio dan Penerapan PPK-BLU

Cash Ratio ini menunjukkan posisi kas yang dapat menutupi hutang lancar. Semakin tinggi rasio ini semakin tinggi pula kemampuan likuiditas rumah sakit yang bersangkutan, namun dalam praktek akan mempengaruhi profitabilitasnya. Maka hipotesis yang diajukan sebagai berikut:

H 1 : Cash Ratiosesudah menerapkan PPK-BLU lebih baik dibandingkan dengan sebelum menerapkan PPK-BLU

2. Current Ratio dan Penerapan PPK-BLU
Current Ratio merupakan rasio untuk mengukur kemampuan perusahaan dalam membayar kewajiban jangka pendek atau utang yang segera jatuh tempo pada saat ditagih secara keseluruhan.Hipotesis kedua yang diajukan adalah sebagai berikut:

\section{H-2 : Current Ratiosesudah menerapkan PPK-BLU lebih baik dibandingkan dengan sebelum menerapkan PPK-BLU}

3. Collection Period dan Penerapan PPK-BLU

Collection Periodmerupakan rasio yang menunjukkan berapa lama perusahaan melakukan penagihan piutang. Semakin pendek periodenya maka akan semakin baik bagi perusahaan. Dalam penelitian ini Collection Periodakan dibandingkan sebelum dan sesudah penerapan PPKBLU.Hipotesis ketiga yang diajukan adalah H-3 : Collection Periodsesudah menerapkan PPK-BLU lebih baik dibandingkan dengan sebelum menerapkan PPK-BLU 
4. Fixed Asset Turnover dan Penerapan PPK-

BLU

Fixed Asset Turnover bertujuan untuk mengidentifikasikan bagaimana aset tetap digunakan untuk menghasilkan pendapatan suatu satker BLU.Semakin besar nilai dari rasio Fixed Asset Turnover menandakan semakin optimal BLU menggunakan assetnya. Berdasar pernyataan tersebut maka hipotesis ketiga yang diajukan berikutnya adalah :

\section{H-4 : Fixed Asset Turnoversesudah} menerapkan PPK-BLU lebih baik dibandingkan dengan sebelum PPK-BLU

5. Return on Asset dan Penerapan PPK-BLU

Rasio ini menunjukan hasil atas jumlah aset yang digunakan dalam perusahaan. Merupakan ukuran efektivitas pimpinan BLU dalam mengelola asetnya. Semakin tinggi kemampuan rumah sakit menghasilkan rasio ini semakin baik penilaiannya, artinya pimpinan BLU berhasil dalam mengelola aset yang dimiliki rumah sakit.. Hipotesis kelima yang diajukan dari penelitian ini adalah :

\section{H-5: Return on AssetRSUP sesudah} menerapkan PPK-BLU lebih baik dibandingkan dengan sebelum menerapkan PPK-BLU

6. Return on Equity dan Penerapan PPK-BLU

Return on Equity merupakan rasio yang digunakan untuk mengukur kinerja manajemen dalam mengelola modal yang tersedia untuk menghasilkan laba setelah pajak. Rasio ini juga dapat menunjukan efisiensi penggunaan modal sendiri. Semakin tinggi rasio ini semakin baik, artinya posisi modal satker BLU semakin kuat. Efektivitas rasio ini akan diuji sebelum dan sesudah penerapan PPKBLU. Hipotesis yang diajukan adalah :

\section{H-6 : Pengukuran Return on Equitysesudah menerapkan PPK- BLU lebih baik dibandingkan dengan sebelum menerapkan PPK-BLU}

7. Sales Growth (SALG) dan Penerapan PPKBLU

Sales Growth (SALG) adalah gambaran tingkat pelayanan yang dapat dilihat dari peningkatan pendapatan Rumah Sakit. Rasio ini dihitung pendapatan periode berjalan dibandingkan dengan pendapatan periode yang lalu. Semakin tinggi rasio ini semakin baik, artinya pertumbuhan pendapatan satker BLU semakin kuat yang menindikasikan banyaknya pelayanan yang diberikan kepada konsumen.Hipotesis yang diajukan adalah:

\section{H-7 : Pengukuran Sales Growth} (SALG)sesudah menerapkan PPKBLU lebih baik dibandingkan dengan sebelum menerapkan PPK-BLU

\section{Activity Growthdan Penerapan PPK-BLU}

Activity Growthadalah gambaran pertumbuhan tingkat pelayanan dari peningkatan volume kegiatan.Rasio ini dihitung volume pelayanan periode berjalan dibandingkan dengan volume pelayanan periode yang lalu.Semakin tinggi rasio ini semakin baik, artinya pelayanan yang diberikan kepada pasien satker BLU semakin banyak. Hipotesis yang diajukan adalah :

\section{H-8: Pengukuran Activity}

Growthsesudah menerapkan PPK-

BLU lebih baik dibandingkan dengan sebelum menerapkan PPK-BLU 


\section{METODE PENELITIAN}

\section{Tempat dan Waktu Penelitian}

Penelitian ini dipilih bertempat di RSUP dr. Soeradji Tirtonegoro atau sebelumnya bernama RSUP Tegalyoso Klaten dengan alamat jalan Dr. Soeradji Tirtonegoro no.1 Klaten, propinsi Jawa Tengah. Waktu penelitian ini dilakukan mulai bulan Oktober 2013 sampai dengan November 2013. Data pengamatan yang digunakan dalam penelitian merupakan laporan keuangan RSUP $d r$. Soeradji Tirtonegoro yang dimulai dari tahun 2002 sampai dengan 2012.

\section{Jenis Penelitian}

Penelitian ini menggunakan metode penelitian deskriptif dan komparatif. Metode deskriptif adalah penelitian yang dilakukan untuk mengetahui nilai variabel mandiri, baik satu variabel atau lebih (independen) tanpa membuat perbandingan, atau menghubungkan dengan variabel lain. Sedangkan metode komparatif adalah suatu penelitian yang bersifat membandingkan keberadaan suatu variabel pada dua sampel atau lebih (Sugiyono, 2000).

Dari pemaparan diatas, peneliti membandingkan kinerja keuangan dan kinerja pelayanan RSUP $d r$. Soeradji Tirtonegorosebelum ditetapkan sebagai Rumah Sakit Pola Pengelolaan Keuangan Badan Layanan Umum dengan kinerja keuangan dan pelayanan setelah ditetapkan sebagai Rumah Sakit Pola Pengelolaan Keuangan Badan Layanan Umum.

\section{Lingkup Penelitian}

Lingkup penelitian dalam penelitian ini adalah laporan keuangan RSUP dr. Soeradji Tirtonegoro berupa laporan semesteran dan tahunan RSUP dr. Soeradji Tirtonegoro selama tahun 2002-2012 dan data kinerja pelayanan, yang kemudian dihitung rasiorasio keuangannya guna menilai kinerja keuangan, seperti yang telah ditentukan dalam Surat Keputusan dari Direktorat Jenderal Perbendaharaan Kementerian Keuangan RI tentang Pedoman Penilaian Kinerja Keuangan Badan Layanan Umum (BLU) yakni Per 36/PB/2012 tanggal 25 Oktober 2012. Kemudian dihitung juga kinerja pelayanannya seperti yang telah ditentukan dalam KEPMENKES NO.209/MENKES/SK/I/2011.

\section{Variabel Penelitian}

Pada dasarnya variabel penelitian adalah segala sesuatu yang berbentuk apa saja yang ditetapkan oleh peneliti untuk dipelajari sehingga diperoleh informasi tentang hal tersebut, kemudian ditarik kesimpulannya. (Sugiyono, 2007).Variabel yang digunakan dalam penelitian ini bersifat independen yang artinya bebas atau tidak terikat oleh variabel lainnnya. Variabel tersebut adalah rasio-rasio keuangan dan pelayanan RSUP $\mathrm{dr}$. Soeradji Tirtonegoro yang terdiri atas: Cash Ratio, Current Ratio, Collection Period, Fixed Asset Turnover, Return on Asset, Return on Equity, Sales Growth (SALG), Activity G rowth.

\section{Definisi dan Pengukuran Variabel}

Definisi dan pengukuran variabel yang dipergunakan dalam penelitan akan dijelaskan dibawah ini :

1. Cash Ratio

Rasio ini menunjukkan posisi kas yang dapat menutupi hutang lancar.Rasio ini adalah rasio yang paling likuid. Semakin tinggi rasio ini semakin tinggi pula kemampuan likuiditas perusahaan yang bersangkutan, namun dalam praktek akan mempengaruhi profitabilitasnya.Dalam Peraturan Dirjen Perbendaharaan NO. PER-36/PB/2012 Cash Ratiodirumuskan sebagai berikut: 


$$
\text { Cash Ratio }=\frac{\text { Kas dan Setara kas }}{\text { Kewajiban jangka pendek }} \times 100 \%
$$

\section{Current Ratio}

Current Ratio merupakan rasio utk mengukur kemampuan perusahaan dalam membayar kewajiban jangka pendek atau utang yang segera jatuh tempo pada saat ditagih secara keseluruhan.Untuk rumus
Current Ratio rumah sakit yang akan digunakan dalam penelitian ini mengacu pada ketentuan pemerintah Peraturan Dirjen Perbendaharaan NO. PER36/PB/2012 :

$$
\text { Current Ratio }=\frac{\text { Asset Lancar }}{\text { Kewajiban jangka pendek }} \times 100 \%
$$

\section{Collection Period}

Collection Periodadalah periode untuk mengumpulkan piutang usaha pada saat jatuh tempo.Efektifitas kebijakan penagihan dapat dievaluasi dengan melihat tingkat biaya piutang tidak tertagih yang juga dipengaruhi oleh kebijakan kredit perusahaan.Dalam Peraturan Dirjen Perbendaharaan NO. PER-36/PB/2012 Collection Period dirumuskan sebagai berikut:

$$
\text { Periode Penagihan Piutang }=\frac{\text { Piutang Usaha } \times 360}{\text { Pendapatan Usaha }}
$$

\section{Fixed Asset Turnover}

Fixed Asset Turnover merupakan rasio yang digunakan untuk mengukur berapa kali dana yang ditanamkan dalam aset tetap berputar dalam satu periode. Atau dengan kata lain untuk mengukur apakah perusahaan sudah menggunakan kapasitas aset tetap sepenuhnya atau belum.Fixed Asset Turnoverdirumuskan dalam peraturan Dirjen Perbendaharaan NO. PER-36/PB/2012 adalah sebagai berikut:

$$
\text { Fixed Asset Turnover }=\frac{\text { Pendapatan Operasional }}{\text { Aset Tetap }}
$$

5. Return on Asset

Return on Assetmerupakan salah satu rasio profitabilitas. ROA menunjukkan kemampuan perusahaan untuk mengukur efektivitas kinerja perusahaan dalam memperoleh laba dengan memanfaatkan aktiva yang dimiliki.Untuk rumus Return on Asset rumah sakit yang akan digunakan dalam penelitian ini sesuai pada ketentuan pemerintah Peraturan Dirjen Perbendaharaan NO. PER-36/PB/2012 :

Surplus atau defisit sebelum

$$
\text { Return on Asset }=\frac{\text { pos keuntungan atau kerugian }}{\text { Asset tetap }} \times 100 \%
$$

6. Return on Equity

Return on Equityadalah perbandingan antara jumlah laba yang tersedia bagi pemilik modal sendiri di satu pihak dengan jumlah modal sendiri yang menghasilkan laba tersebut di lain pihak. Return on Equity dirumuskan dalam ketentuan pemerintah Peraturan Dirjen Perbendaharaan NO. PER-36/PB/2012 sebagai berikut: 


$$
\text { Return on Equity }=\frac{\begin{array}{c}
\text { Surplus atau defisit sebelum } \\
\text { pos keuntungan atau kerugian }
\end{array}}{\text { Ekuitas }} \times 100 \%
$$

\section{Sales Growth (SALG)}

Sales Growth adalah gambaran tingkat pelayanan yang dapat dilihat dari peningkatan pendapatan Rumah

$$
\text { Sales Growth }(\text { SALG })=\frac{\text { Pendapatan Brutto Tahun Berjalan }}{\text { Pendapatan Brutto Tahun Lalu }}
$$

8. Activity Growth

Activity Growth adalah gambaran pertumbuhan tingkat pelayanan dari peningkatan volume kegiatan.Berdasar

$$
\text { Activity Growth }=\frac{\text { Volume Pelayanan Tahun Berjalan }}{\text { Volume Pelayanan Tahun Lalu }}
$$

\section{Teknik Pengumpulan Data}

Pengumpulan data dalam penelitian menggunakan teknik pengumpulan data dokumentasi yaitu mengumpulkan dan mempelajari data mengenai hal-hal berupa catatan, transkrip, buku, surat kabar, majalah, prasasti, notulen, agenda dan sebagainya yang akan diteliti. Pengumpulan data yang dilakukan dalam penelitian ini dibagi dengan 2 tahap, yaitu Studi pustaka dan Pengumpulan data sekunder melalui RSUP dr. Soeradji Tirtonegoroyang berisi
KEPMENKES NO. 209/MENKES/SK/I/2011 perhitungan rasio ini adalah sebagai berikut: laporan keuangan dan kinerja pelayanan tahun 2002-2012.

\section{HASI L DAN PEMBAHASAN}

\section{Deskripsi Statistik}

Statistik deskriptif yang digunakan untuk menganalisis data adalah dengan cara mendiskripisikan data yang telah terkumpul sebagaimana adanya tanpa bermaksud membuat kesimpulan yang berlaku untuk umum atau generalisasi. 
Jurnal Bisnis \& M anajemen

Vol. 15, N 0. 1, $2015: 57$ - 80

Tabel 1. Hasil Diskripsi Statistik

\begin{tabular}{|l|c|r|r|r|r|}
\hline & $\mathrm{N}$ & Minimum & Maximum & Mean & \multicolumn{1}{|c|}{$\begin{array}{c}\text { Std. } \\
\text { Deviation }\end{array}$} \\
\hline Cash Ratio Sebelum BLU & 10 & 0,004 & 0,929 & 0,57711 & 0,331919 \\
Cash Ratio Sesudah BLU & 10 & 1,580 & 7,324 & 3,89342 & 2,237893 \\
Current Ratio Sebelum BLU & 10 & 1,314 & 46,345 & 8,53167 & 13,930865 \\
Current Ratio Sesudah BLU & 10 & 3,024 & 22,145 & 7,67495 & 5,802365 \\
Collection Period Sebelum BLU & 10 & 38 & 182 & 107,80 & 54,383 \\
Collection Period Sesudah BLU & 10 & 34 & 337 & 127,70 & 88,921 \\
Fixed Asset Turnover Sebelum BLU & 10 & 0,139 & 1,059 & 0,52839 & 0,353122 \\
Fixed Asset Turnover Sesudah BLU & 10 & 0,248 & 0,999 & 0,49199 & 0,251962 \\
ROA Sebelum BLU & 10 &,- 722 & 0,580 &,- 00862 & 0,421168 \\
ROA Sesudah BLU & 10 & 0,090 & 0,720 & 0,22078 & 0,189477 \\
ROE Sebelum BLU & 10 &,- 115 & 0,416 & 0,09116 & 0,194130 \\
ROE Sesudah BLU & 10 & 0,060 & 0,605 & 0,17128 & 0,163137 \\
Sales Growth Sebelum BLU & 10 & 0,939 & 1,330 & 1,13600 & 0,135088 \\
Sales Growth Sesudah BLU & 10 & 0,838 & 1,400 & 1,14000 & 0,1635713 \\
Activity Growth Sebelum BLU & 10 & 0,918 & 1,163 & 1,03030 & 0,072463 \\
Activity Growth Sesudah BLU & 10 & 0,965 & 1,095 & 1,03738 & 0,040969 \\
Valid N (listwise) & 10 & & & & \\
\hline
\end{tabular}

Sumber : Data Primer Diolah

Dari tabel 1 dapat dilihat hasil dari ringkasan statistik dari sampel penelitian yang berjumlah 8 dapat dijelasakan sebagai berikut:

1. Untuk cash ratio dengan jumlah sampel 10 , sebelum penerapan BLU mempunyai nilai rata-rata 0,57711 dengan setandar deviasi 0,331919, nilai terting i 0,929 dan nilai terendah sebesar 0,004. Sedangkan untuk cash ratio sesudah penerapan BLU mempunyai nilai terting gi 7,324 terendah 1,580 dengan nilai rata-rata 3,89342 standar deviasi 2,237893.

2. CurrentRatiosebelum penerapan BLU mempunyai nilai rata-rata 8,53167 standar deviasi 13,930865 dengan nilai tertinggi 46,345 dan nilai terendah 1,314. Untuk CurrentRatiosesudah penerapan BLU nilai rata-rata 7,67495 standar deviasi 5,802365 dengan nilai tertinggi 7,67495 dan nilai terendah 3,024.

3. Untuk besarnya nilai rata-rata dari CollectionPeriodSebelum penerapan BLU107,80 dengan standar deviasi 54,383, nilai terendah 38 dan tertinggi 182. Pada CollectionPeriod sesudah penerapan BLU nilai tertinggi 337 dan terendah 334 untuk nilai rata-rata didapat sebesar 127 dengan standar deviasi 88,921.

4. FixedAssetTurnover sebelum penerapan BLU mempunyai nilai tertinggi 1,059 , terendah 0,139 dengan nilai rata-rata sebesar 0,52839 dan standar deviasinya 0,353122 . Pada nilai rata-rata FixedAssetTurnover setelah penerapan BLU adalah 0,49199 dengan standar deviasi 0,251962, untuk nilai tertinggi sebesar 0,999 dan terendah 0,248. 
5. Nilai terendah dari ROA sebelum penerapan BLU sebesar -0,722 dan tertinggi mempunyai nilai 0,580 , untuk besaran nilai rata-rata $-0,00862$ dan besar standar deviasinya sebesar 0,421168 . Hasil nilai tertinggi ROA sesudah penerapan BLU mempunyai nilai sebesar 0,720 terendah 0,090 dengan nilai ratarata sebesar 0,22078 dan standar deviasinya 189477.

6. Nilai tertinggi dari ROE sebelum penerapan BLU sebesar $-0,416$ dan nilai terendah $-0,115$. ROE sebelum penerapan BLU mempunyai besaran nilai rata-rata $-0,00862$ dan besar standar deviasinya sebesar 0,421168 . Untuk nilai tertinggi ROE sesudah penerapan BLU mempunyai nilai sebesar 0,720 terendah 0,090 dengan nilai rata-rata sebesar 0,17128 dan standar deviasinya 0,163137 .

7. SalesGrowthsebelum penerapan BLU mempunyai nilai rata-rata 1,136000 standar deviasi 0,135088 dengan nilai terting gi 1,330 dan nilai terendah 0,939. Untuk SalesGrowth sesudah penerapan
BLU nilai rata-rata 1,14000 standar deviasi 0,163571 dengan nilai terting gi 1,400 dan nilai terendah 0,838 .

8. Untuk besarnya nilai rata-rata dari Sales ActivitySebelum penerapan BLU1,03030 dengan standar deviasi 0,072463, nilai terendah 0,918 dan terting gi 1,163. Pada Sales Activity sesudah penerapan BLU nilai terting i 1,095 dan terendah 0,965 untuk nilai rata-rata didapat sebesar 1,03738 dengan standar deviasi ,040969.

\section{Uji Normalitas}

Uji normalitas berguna untuk menentukan data yang telah dikumpulkan berdistribusi normal atau diambil dari populasi normal.Uji normalitas yang digunakan dalam penelitian ini adalah uji normalitas dengan Kolmogorov Smirnov. Pengambilan keputusan uji normalitas Kolmogorov Smirnov adalah jika nilai signifikan ditentukan sebesar 0,05, apabila $p$ $>0,05$ maka distribusi data normal, apabila $p<0,05$ maka distribusi data tidak normal.
Tabel 2Hasil Uji Normalitas Kolmogorov Smirnov
Kolmogorov-Smirnov

$\mathrm{Z}$

0,516

0,583

1,248

0,826

0,497

0,775

0,930

0,710

0,629
Asymp. Sig.

(2-tailed)

0,953

0,886

0,089

0,503

0,966

0,586

0,352

0,695

0,823 
Jurnal Bisnis \& $M$ anajemen

Vol. 15, N 0. 1, 2015: 57 - 80

ROA Sesudah BLU

0,911

0,378

ROE Sebelum BLU

0,643

0,803

ROE Sesudah BLU

0,976

Sales Growth Sebelum BLU

0,894

0,400

Sales Growth Sesudah BLU

0,835

0,489

Activity Growth Sebelum BLU

0,492

0,969

Activity Growth Sesudah BLU

0,414

0,996

\section{Sumber : Data Primer Diolah}

Dari tabel 2 dapat dilihat nilai signifikan/Asymp. Sig. (2-tailed) Cash Ratio, Current Ratio, Collection Period, Fixed Asset Turnover, Return on Asset, Return on Equity, Sales Growth, Activity GrowthRSUP dr. Soeradji Tirtonegoro sebelum dan sesudah penerapan BLU lebih besar dari 0,05 sehingga dapat disimpulkan bahwa data yang dipergunakan penelitianberdistribusi

\section{Uji Hipotesis dan Pembahasan}

Untuk uji hipotesis dalam penelitian ini dibagi kedalam 2 kelompok.Kelompok 1 adalah indikator kinerja keuangan(hipotesis 1- hipotesis 6), sedangkan kelompok 2 adalah indikator kinerja pelayanan (hipotesis 7 dan hipotesis 8).

\section{Hipotesis 1}

\section{Tabel 3 Hasil Uji BedaT-testCash Ratio}

Paired Samples Test

\begin{tabular}{|c|c|c|c|}
\hline & Pair 1 \\
\hline & & & $\begin{array}{c}\text { Cash Ratio Sebelum BLU Cash Ratio } \\
\text { Sesudah BLU }\end{array}$ \\
\hline \multirow{5}{*}{$\begin{array}{l}\text { Paired } \\
\text { Differences }\end{array}$} & \multirow{5}{*}{$\begin{array}{l}\text { Mean } \\
\text { Std. Deviation } \\
\text { Std. Error Mean } \\
\text { 95\% Confidence Interval } \\
\text { of the Difference }\end{array}$} & & -3.32 \\
\hline & & & 2.22 \\
\hline & & & 0,703139 \\
\hline & & Lower & $-4,906921$ \\
\hline & & Upper & $-1,725699$ \\
\hline \multirow{3}{*}{\multicolumn{3}{|c|}{$\begin{array}{l}\text { T } \\
\text { Df } \\
\text { Sig. (2-tailed) }\end{array}$}} & $-4,716$ \\
\hline & & & 9 \\
\hline & & & 0,001 \\
\hline
\end{tabular}

Sumber : Data Primer Diolah 
Berdasarkan hasil perhitungan tabel 3, nilai t hitung cash ratio sebesar -4.716 dengan probabilitas 0.001 . Jika dibandingkan nilai signifikasi < 0.05 maka dapat disimpulkan bahwa Ho ditolak, artinya Cash RatioRSUP dr. Soeradji Tirtonegoro sesudah menerapkan PPK-BLU lebih baik dibandingkan dengan sebelum PPK-BLU.
Dari hasi uji hipotesis 1 terseb ut maka penerapan BLU pada RSUP dr. Soeradji Tirtonegoro memang memberikan perubahan. Hal ini sesuai dengan tujuan penerapan BLU yaitu memberikan keleluasan kepada rumah sakit mengelola keuangannya sendiri.

\section{Hipotesis 2}

Tabel 4Hasil Uji Beda T-testCurrent Rati, Paired Samples Test

\begin{tabular}{|c|c|c|c|}
\hline & Pair 1 \\
\hline & & & $\begin{array}{l}\text { Current Ratio Sebelum BLU - } \\
\text { Current Ratio Sesudah BLU }\end{array}$ \\
\hline \multirow[t]{5}{*}{ Paired Differences } & \multicolumn{2}{|l|}{ Mean } & 0,856720 \\
\hline & \multicolumn{2}{|l|}{ Std. Deviation } & 15,953530 \\
\hline & \multicolumn{2}{|l|}{ Std. Error Mean } & 5,044949 \\
\hline & \multirow{2}{*}{$\begin{array}{l}95 \% \text { Confidence Interval } \\
\text { of the Difference }\end{array}$} & Lower & $-10,555748$ \\
\hline & & Upper & 12,269188 \\
\hline \multicolumn{3}{|l|}{$\mathrm{T}$} & 0,170 \\
\hline \multicolumn{3}{|l|}{ Df } & 9 \\
\hline \multicolumn{3}{|l|}{ Sig. (2-tailed) } & 0,869 \\
\hline
\end{tabular}

Dari hasil perhitungan tabel 4 dapat dilihat bahwa Current Ratio dalam penelitian ini terlihat mempunyai $t$ hitung sebesar 0,170 dengan probabilitas 0.869 . Jika dibandingkan nilai signifikasi > 0.05 maka dapat disimpulkan bahwa Ho diterima, artinya tidak ada perbedaan signifikan Current RatioRSUP dr. Soeradji Tirtonegoro sesudah menerapkan PPK-BLU dengan sebelum PPK-BLU.Dari hasi uji hipotesis 2 tersebut maka dapat disimpulkan bahwa penerapan BLU pada RSUP $d r$. Soeradji
Tirtonegoro tidak memberikan perubahan yang signifikan pada current ratio. Hal ini menunjukkan nilai kekayaan lancar yang digunakan untuk menutup utang tidak terjadi perbedaan dengan adanya penerapan BLU pada RSUP dr. Soeradji Tirtonegoro. Setelah penerapan BLU, rumah sakit diperkenankan mengelola hutang sehingga nilai hutang tinggi. Meskipun kalau dilihat dari tahun ke tahun setelah BLU sebenarnya ada pening katan nilai current ratio 
Jurnal Bisnis \& $M$ anajemen

Vol. 15, N 0. 1, 2015: $57-80$

\section{Hipotesis 3}

Tabel 5 Hasil Uji Beda T-testCollection Period, Paired Samples Test

\begin{tabular}{|c|c|c|c|}
\hline & Pair 1 \\
\hline & & & $\begin{array}{l}\text { Collection Period Sebelum BLU - } \\
\text { Collection Period Sesudah BLU }\end{array}$ \\
\hline \multirow[t]{5}{*}{ Paired Differences } & \multicolumn{2}{|l|}{ Mean } & $-19,900$ \\
\hline & \multicolumn{2}{|l|}{ Std. Deviation } & 69,864 \\
\hline & \multicolumn{2}{|l|}{ Std. Error Mean } & 22,093 \\
\hline & \multirow{2}{*}{$\begin{array}{l}95 \% \text { Confidence Interval } \\
\text { of the Difference }\end{array}$} & Lower & $-69,878$ \\
\hline & & Upper & 30,078 \\
\hline \multicolumn{3}{|l|}{$\mathrm{T}$} & $-0,901$ \\
\hline \multicolumn{3}{|l|}{ df } & 9 \\
\hline \multicolumn{3}{|l|}{ Sig. (2-tailed) } & 0,391 \\
\hline
\end{tabular}

Sumber : Data Primer Diolah

Dari tabel 5 diatas dapat dilihat nilai $\mathrm{t}$ hitung yang didapat dari Collection Perioddalam dalam penelitian ini sebesar 0,901 dengan probabilitas 0.391 . Jika dibandingkan nilai signifikasi > 0.05 maka dapat disimpulkan bahwa Ho diterima, artinya Tidak ada perbedaan signifikan Collection PeriodRSUP $d r$. Soeradji Tirtonegoro sesudah menerapkan PPK-BLU dengan sebelum PPK-BLU.

Dari hasil uji hipotesis 3 tersebut maka dapat disimpulkan bahwa penerapan BLU pada RSUP dr. Soeradji Tirtonegoro tidak memberikan perubahan yang signifikan pada current ratio. Hal ini menunjukkan periode penagihan piutang tidak terjadi perbedaan dengan adanya penerapan BLU pada RSUP dr. Soeradji Tirtonegoro.

Permasalahan yang timbul

disebabkan karena :

a. Sejak tahun 2008 piutang jamkesda yang dilayani Dinas Kesehatan Kab Klaten dan Syari'ah Mubarokah (sebagai pemenang tender) pembayarannya tidak lancar sampai kurang lebih selama 3 tahun

b. Luncuran dana jamkesmas dari pusat kurang lancar, sehingga berakibat angka piutang tinggi

c. Pengajuan tagihan jamkesmas juga ada beberapa hambatan/keterlambatan terkait permasalahan pada software INA CBG's yang sering update dan ada masalah. 


\section{Hipotesis 4}

Tabel 6 Hasil Uji Beda T-testFixed Asset Turnover

\begin{tabular}{|c|c|c|c|}
\hline \multicolumn{4}{|c|}{ Paired Samples Test } \\
\hline & & & Pair 1 \\
\hline & & & $\begin{array}{l}\text { Fixed Asset Turnover Sebelum BLU - } \\
\text { Fixed Asset Turnover Sesudah BLU }\end{array}$ \\
\hline \multirow{5}{*}{$\begin{array}{l}\text { Paired } \\
\text { Differences }\end{array}$} & \multirow{5}{*}{$\begin{array}{l}\text { Mean } \\
\text { Std. Deviation } \\
\text { Std. Error Mean } \\
95 \% \text { Confidence Interval } \\
\text { of the Difference }\end{array}$} & & 0,036400 \\
\hline & & & 0,358647 \\
\hline & & & 0,113414 \\
\hline & & Lower & $-0,220161$ \\
\hline & & Upper & 0,292961 \\
\hline $\mathrm{t}$ & & & 0,321 \\
\hline df & & & 9 \\
\hline Sig. (2-tailed) & & & 0,756 \\
\hline
\end{tabular}

Sumber : Data Primer Diolah

Dari tabel 6 dapat dilihat bahwa nilai thitung dari Fixed Asset Turnover dalam penelitian ini sebesar 0,321 dengan probabilitas 0.756 . Jika dibandingkan nilai signifikasi $>0.05$ maka dapat disimpulkan bahwa Ho diterima, artinya tidak ada perbedaan signifikan Fixed Asset TurnoverRSUP dr. Soeradji Tirtonegoro sesudah menerapkan PPK-BLU dengan sebelum PPK-BLU.

Dari hasi uji hipotesis 4 tersebut maka dapat disimpulkan bahwa penerapan BLU pada RSUP dr. Soeradji Tirtonegoro tidak memberikan perubahan pada Fixed Asset Turnover. Hal ini menunjukkan perputaran aktiva tetap tidak terjadi perbedaan dengan adanya penerapan BLU pada RSUP $\mathrm{dr}$. Soeradji Tirtonegoro.

Tidak adanya perubahan yang signifikan pada Fixed Asset Turnover disebabkan dari sisi pendapatan operasional, setelah BLU meningkat cukup tajam, akan tetapi karena setelah penerapan BLU investasi yang dilakukan pada 'asset tetap' juga terjadi peningkatan cukup besar, dikarenakan Rumah Sakit BLU diperkenankan melakukan investasi dari dana BLU, maka hasil rasio Fixed Asset Turnover setelah BLU tidak meningkat tajam.

\section{Hipotesis 5}

Hipotesis 5 yang dibuktikan dalam penelitian ini adalah ada tidaknya perbedaan yang signifikan rasio Return on Asset (ROA)RSUP dr. Soeradji Tirtonegoro sesudah menerapkan PPK-BLU dengan sebelum PPKBLU. 
Jurnal Bisnis \& M anajemen

Vol. 15, N 0. 1, $2015: 57$ - 80

Tabel 7 Hasil Uji Beda T-testReturn on Asset (ROA)

Paired Samples Test

\begin{tabular}{|c|c|c|c|}
\hline & & & Pair 1 \\
\hline & & & $\begin{array}{c}\text { ROA Sebelum BLU - ROA } \\
\text { Sesudah BLU }\end{array}$ \\
\hline Paired Differences & Mean & & $-0,229400$ \\
\hline & Std. Deviation & & 0,544392 \\
\hline & Std. Error Mean & & 0,172152 \\
\hline & 95\% Confidence Interval & Lower & $-0,618834$ \\
\hline & of the Difference & Upper & 0,160034 \\
\hline $\mathrm{t}$ & & & $-1,333$ \\
\hline df & & & 9 \\
\hline Sig. (2-tailed) & & & 0,215 \\
\hline
\end{tabular}

Sumber : Data Primer Diolah

Pada tabel 7 didapati bahwa nilai t hitung dari Return on Asset (ROA) dalam penelitian ini sebesar $-1,333$ dengan probabilitas 0.215 . Jika dibandingkan nilai signifikasi $>$ 0.05 maka dapat disimpulkan bahwa Ho diterima, artinya Tidak ada perbedaan signifikan Return on Asset (ROA)RSUP dr. Soeradji Tirtonegoro sesudah menerapkan PPK-BLU dengan sebelum PPK-BLU.

Dari hasi uji hipotesis 5 tersebut maka dapat disimpulkan bahwa penerapan BLU pada RSUP dr. Soeradji Tirtonegoro tidak memberikan perubahan yang signifikan pada Return on Asset(ROA). Hal ini menunjukkan kemampuan manajemen dalam mendapat imbalan yang memadai (reasobable return) dari asset yang dikuasainyatidak terjadi perbedaan dengan adanya penerapan BLU pada RSUP $d r$. Soeradji Tirtonegoro.
ROA setelah penerapan BLU sebenarnya meningkat cukup besar, akan tetapi dikarenakan kenaikan asset setelah penerapan BLU juga besar, sedangkan dana yang dipergunakan untuk investasi yang bersumber dari dana BLU terus bertambah. Selain itu pada tahun 2010 terjadi perubahan peraturan tentang penyusutan yang berakibat beban penyusutan jauh lebih besar, sehingga berdampak biaya operasional melonjak tinggi yang akhirnya berdampak pada return (SHU) menurun.

\section{Hipotesis 6}

Pada hipotesis penelitian 6 akan dibuktikan bahwa ada perbedaan yang signifikan rasio Return on Equity (ROE)RSUP dr. Soeradji Tirtonegoro sesudah menerapkan PPK-BLU dengan sebelum menerapkan PPK-BLU. 
Tabel 8 Hasil Uji Beda T-testReturn on Equity (ROE)

Paired Samples Test

\begin{tabular}{|c|c|c|c|}
\hline & & & Pair 1 \\
\hline & & & $\begin{array}{l}\text { ROE Sebelum BLU - } \\
\text { ROE Sesudah BLU }\end{array}$ \\
\hline Paired Differences $\mathrm{N}$ & Mean & & $-0,080120$ \\
\hline & Std. Deviation & & 0,289744 \\
\hline & Std. Error Mean & & 0,091625 \\
\hline & $95 \%$ Confidence Interval & Lower & $-0,287391$ \\
\hline & of the Difference & Upper & 0,127151 \\
\hline $\mathrm{T}$ & & & $-0,874$ \\
\hline df & & & 9 \\
\hline Sig. (2-tailed) & & & 0,405 \\
\hline
\end{tabular}

Sumber : Data Primer Diolah

Berdasar pada tabel 8 didapati bahwa nilai t hitung dari Return on Equity (ROE)yang terdapat dari tabel sebesar -0,874 dengan probabilitas 0.215 . Jika dibandingkan nilai signifikasi > 0.05 maka dapat disimpulkan bahwa Ho diterima, artinya Tidak ada perbedaan signifikan Return on Equity (ROE)RSUP dr. Soeradji Tirtonegoro sesudah menerapkan PPK-BLU dengan sebelum PPKBLU.

Dari hasi uji hipotesis 6 tersebut maka dapat disimpulkan bahwa penerapan BLU pada RSUP $d r$. Soeradji Tirtonegoro tidak memberikan perubahan pada Return on Equity(ROE). Hal ini menunjukkan kemampuan manajemen dalampengembalian besarnya modal dari rumah sakittidak terjadi perbedaan dengan adanya penerapan BLU pada RSUP $d r$. Soeradji Tirtonegoro.

Kemampuan

manajemen dalampengembalian besarnya modal dari rumah sakittidak terjadi perbedaan disebabkan banyaknya dana yang dipergunakan untuk melakukan investasi pengembangan asset bagi rumah sakit.

\section{Hipotesis 7}

Untuk hipotesis 7 yang dibuktikan dari penelitian ini adalah adanya perbedaan signifikan Sales GrowthRSUP dr. Soeradji Tirtonegoro sesudah menerapkan PPK-BLU dengan sebelum PPK-BLU. 
Jurnal Bisnis \& M anajemen

Vol. 15, N 0. 1, $2015: 57$ - 80

\section{Tabel 9 Hasil Uji Beda T-testSales Growth}

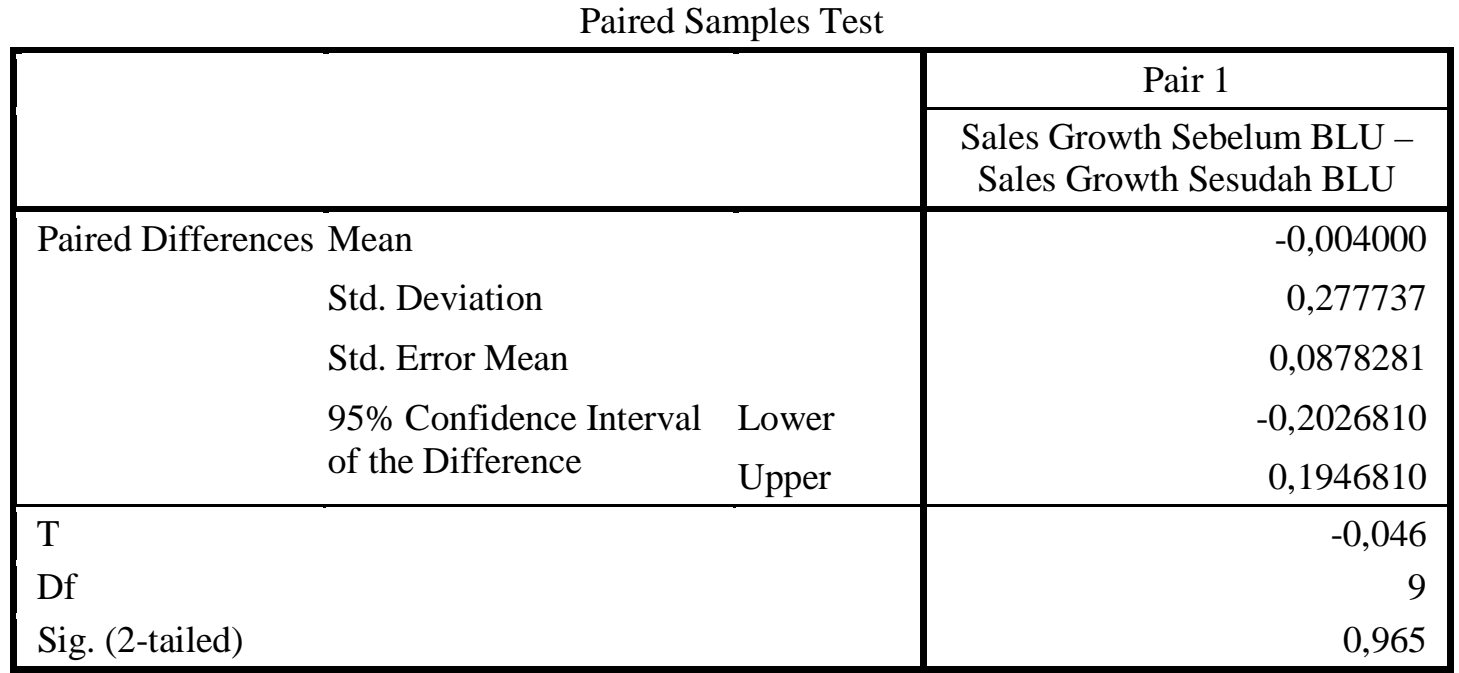

Sumber : Data Primer Diolah

Hasil yang dapat dilihat pada tabel 9 didapati bahwa nilai $t$ hitung dari Sales Growth dalam penelitian ini sebesar $-0,046$ dengan probabilitas 0.965 . Jika dibandingkan nilai signifikasi > 0.05 maka dapat disimpulkan bahwa Ho diterima, artinya tidak ada perbedaan signifikan Sales GrowthRSUP dr. Soeradji Tirtonegoro sesudah menerapkan PPK-BLU dengan sebelum menerapkan PPK-BLU.

Dari hasi uji hipotesis 7 tersebut maka dapat disimpulkan bahwa penerapan BLU pada RSUP dr. Soeradji Tirtonegoro tidak memberikan perubahan yang signifikan pada Sales Growth. Hal ini menunjukkan bahwa kemampuan manajemen dalampeningkatan pelayanan yang dapat dilihat dari peningkatan pendapatan Rumah Sakittidak terjadi perbedaan dengan adanya penerapan BLU pada RSUP dr. Soeradji Tirtonegoro.

Kemampuan RSUP dr. Soeradji Tirtonegoro dalam melayani pasien terkendala dengan kapasitas. Usaha yang dilakukan untuk meningkatkan pelayanan adalah sejak tahun 2010 RSUP dr. Soeradji Tirtonegoro sedang mengadakan investasi pembelian tanah/lahan yang direncanakan ke depan akan digunakan memperbesar kapasitas sehingga dapat meningkatkan pelayanannya.

\section{Hipotesis 8}

Dalam hipotesis 8 yang dibuktikan dari penelitian ini bahwa ada perbedaan signifikan Activity GrowthRSUP dr. Soeradji Tirtonegoro sesudah menerapkan PPK-BLU dengan sebelum PPK-BLU. 
Tabel 10 Hasil Uji Beda T-testActivity Growth

\begin{tabular}{|c|c|c|}
\hline \multicolumn{3}{|c|}{ Paired Samples Test } \\
\hline & & Pair 1 \\
\hline & & $\begin{array}{l}\text { Activity Growth Sebelum BLU - } \\
\text { Activity Growth Sesudah BLU }\end{array}$ \\
\hline \multicolumn{2}{|c|}{ Paired Differences Mean } & $-0,007080$ \\
\hline & Std. Deviation & 0,070066 \\
\hline & Std. Error Mean & 0,022157 \\
\hline & $95 \%$ Confidence Interval Lower & $-0,057202$ \\
\hline & of the Difference Upper & 0,043042 \\
\hline $\mathrm{T}$ & & $-0,320$ \\
\hline Df & & 9 \\
\hline Sig. (2-tailed) & & 0,757 \\
\hline
\end{tabular}

Sumber :Data Primer Diolah

Berdasar pada hasil perhitungan dari pengujian Uji Beda T-testActivity Growth yang terlihat pada table10 didapati bahwa nilai $t$ hitung sebesar $-0,320$ dengan probabilitas 0.757 . Jika dibandingkan nilai signifikasi > 0.05 maka dapat disimpulkan bahwa Ho diterima, artinya Tidak ada perbedaan signifikan Activity Growth RSUP dr. Soeradji Tirtonegoro sesudah menerapkan PPK-BLU dengan sebelum PPKBLU.

Dari hasi uji hipotesis 8 tersebut maka dapat disimpulkan bahwa penerapan BLU pada RSUP dr. Soeradji Tirtonegoro tidak memberikan perubahan yang signifikan pada Activity Growth. Hal ini menunjukkan kemampuan manajemen dalammeningkatkan pertumbuhan tingkat pelayanan yang dilihat dari peningkatan volume kegiatantidak terjadi perbedaan dengan adanya penerapan BLU pada RSUP Dr. Soeradji Tirtonegoro.

Permasalahan yang dihadap pada Activity Growthsama halnya dengan Sales Growth. Keterbatasan kapasitas daya tampung menjadi kendala RSUP Dr. Soeradji Tirtonegoro untuk meningkatkan sales growthnya.Solusi yang dilakukan pada saat ini adalah dengan melakukan investasi memperluas gedung dan menambah fasilitas pelayanan Rawat Jalan untuk meningkatkan pelayanannya.

\section{SIMPULAN}

\section{Simpulan}

Berdasarkan hasil analisis data dan pembahasan yang diperoleh saat penelitian, maka terdapat beberapa kesimpulan sebagai berikut:

1. Berdasarkan hasil analisa uji beda menggunakan analisis Uji Beda T-test untuk menguji kinerja keuangan RSUP $d r$. Soeradji Tirtonegoro sebelum dan sesudah penerapan BLU, menunjukkan bahwa kinerja keuangansecara keseluruhanRSUP dr. Soeradji Tirtonegoro sesudah menerapkan PPKBLU tidak menunjukkan perbedaan yang signifikan dibandingkan sebelum menerapkan PPK BLU, meskipun rasio keuangannya sesudah menerapkan PPK BLU menunjukkan kenaikan dibandingkan dengan sebelum PPK-BLU.

2. Berdasarkan hasil analisa uji beda menggunakan analisis Uji Beda T-test untuk menguji kinerja pelayanan RSUP $d r$. Soeradji Tirtonegoro sebelum dan sesudah penerapan BLU, menunjukkan 
bahwa kinerja pelayananRSUP dr. Soeradji Tirtonegoro sesudah menerapkan PPKBLU tidak menunjukkan perbedaan yang signifikan dibandingkan sebelum menerapkan PPK BLU, meskipun rasio keuangannya sesudah menerapkan PPK BLU menunjukkan kenaikan dibandingkan dengan sebelum PPK-BLU.

3. Cash Ratio RSUP dr. Soeradji Tirtonegoro memiliki perbedaan yang signifikan sesudah menerapkan PPK-BLU dengan sebelum PPK-BLU

4. Current Ratio RSUP dr. Soeradji Tirtonegoro tidak memiliki perbedaan yang signifikan sesudah menerapkan PPK-BLU dengan sebelum PPK-BLU.

5. Collection Period RSUP dr. Soeradji Tirtonegoro tidak memiliki perbedaan yang signifikan sesudah menerapkan PPK-BLU dengan sebelum PPK-BLU.

6. Fixed Asset Turnover RSUP dr. Soeradji Tirtonegoro tidak memiliki perbedaan yang signifikan sesudah menerapkan PPK-BLU dengan sebelum PPK-BLU.

7. Return on AssetRSUP dr. Soeradj i Tirtonegoro tidak memiliki perbedaan yang signifikan sesudah menerapkan PPK-BLU dengan sebelum PPK-BLU.

8. Return on Equity RSUP $d r$. Soeradji Tirtonegoro tidak memiliki perbedaan yang signifikan sesudah menerapkan PPK-BLU dengan sebelum PPK-BLU.

9. Sales Growth RSUP dr. Soeradji Tirtonegoro tidak memiliki perbedaan yang signifikan sesudah menerapkan PPK-BLU dengan sebelum PPK-BLU.

10. Activity Growth RSUP dr. Soeradji Tirtonegoro tidak memiliki perbedaan yang signifikan sesudah menerapkan PPK-BLU dengan sebelum PPK-BLU.

\section{Saran}

Hasil dari penelitian ini masih memiliki keterbatasan dan kelemahan. Oleh karena itu untuk lebih menyempurnakan hasil penelitian ini, maka saran yang dapat disampaikan antara lain:
1. Secara umum manajemen RSUP $d r$. Soeradji Tirtonegoro disarankan untuk dapat membuat kebijakan-kebijakan yang dapat meningkatkan kinerja keuangannya maupun kinerja pelayanannya sehingga penerapan BLU di RSUP dr. Soeradji Tirtonegoro dapat membawa kebaikan bagi semua pihak.

2. RSUP Dr. Soeradji Tirtonegoro Klaten disarankan untuk dapat bernegosiasi kembali dengan Pemerintah terkait dengan luncuran dana Jamkesmas agar lebih lancar dan tepat waktu, serta meninjau kembali jadwal penagihan piutang agar lebih diperketat, sehingga periode penagihan piutang tidak terlalu panjang.

3. RSUP Dr. Soeradji Tirtonegoro Klaten disarankan untuk dapat memanfaatkan dana cash atau idle cash yang cukup besar untuk investasi khususnya dalam untuk pengembangan pelayanan agar dana idle cash tidak terlalu besar dan bermanfaat untuk peningkatan kinerja pelayanan.

4. RSUP Dr. Soeradji Tirtonegoro Klaten disarankan untuk mempercepat penataan lokasi dan perluasan lahan agar dapat meningkatkan kembali pelayanan yang telah optimum, sehingga activity growth meningkat.

5. Untuk peneliti selanjutnya agar bisa meneliti masalah kinerja pelayanan dengan lebih lengkap dan dapat menggunakan data triwulan atau bulanan sehingga penelitian bisa mendapat hasil yang optimal.

\section{DAFTAR PUSTAKA}

Bastian, I. 2006.Akuntansi Sektor Publik Suatu Pengantar. Erlangga, Jakarta.

Keputusan Menteri Kesehatan Republik Indonesia Nomor 1204/Menkes/SK/X/2004.

Keputusan Menteri Kesehatan Republik Indonesia Nomor 209/MENKES/SK/I/2011. 
Maharani,A. 2013.Analisis Kinerja Keuangan Sebelum dan Sesudah Penerapan Pola Pengelolaan Keuangan Badan Layanan Umum, Jupe UNS, Vol. 1, No. 3, Hal 110.

Mahmudi. 2005.Manajemen Kinerja Sektor Publik.UPP AMP YKPN: Yogyakarta.

Mowen, Hansen. 2006. Management Accounting, Edisi 7. Salemba Empat: Jakarta.

Munawir. 2001.Akuntansi Keuangan dan Manajemen, Edisi Pertama, BPFE:Yogyakarta.

Munawir. 2005.Analisa Laporan Keuangan. Liberty: Yogyakarta.

Peraturan Direktur Jenderal Perbendaharaan Nomor Per-36/PB/2013.

Peraturan Pemerintah Nomor 23 Tahun 2005 tentang Pengelolaan Keuangan Badan Layanan Umum.
Sawir,A.2005.Analisis Kinerja Keuangan dan Perencanaan Keuangan Perusahaan. PT. Gramedia Pustaka Utama:Jakarta.

Simamora,H. 2006. Manajemen Sumber Daya Manusia. STIE:Yogyakarta.

Sugiyono. 2000.Statistik Untuk Penelitian. CV. Alfabeta:Bandung.

Sutrisno. 2005.Manajemen Keuangan Teori, Konsep, dan Aplikasi. Ekonisi:Yogyakarta.

Trianasari, E. danIdrus, Muhammad Syafiien. 2012.Evaluasi Strategi RSUD Dr. Saiful Anwar (RSSA) Malang sebelum dan sesudah Badan Layanan Umum Daerah (BLUD), Tesis,Jurusan Manajemen Fakultas Ekonomi dan Bisnis Universitas Brawijaya Malang.

UU Nomor 1 Tahun 2004 tentang

Perbendaharaan Negara. 
Jurnal Bisnis \& $M$ anajemen

Vol. 15, N 0. 1, 2015: 57 - 80 